\title{
SCIDoc

\section{Vitamin D Deficiency in a Sunny Country: The Missing Chain}

Review Article

Al-Jurayyan NA

Professor and Senior Consultant Pediatric Endocrinologist, Division of Endocrinology, Department of Pediatrics, College of Medicine, King Saud University, Riyadh, Saudi Arabia.

\section{Abstract}

Vitamin D deficiency continues to be an important health problem around the world. It has been reported in healthy children, young adults, middle age adults and elderly, and common among both males and females. Recent studies have shown that Vitamin D deficiency or insufficieny are associated with other pathologic conditions. Vitamin D plays an important role in skeletal development and bone health maintenance. Because the symptoms and signs of Vitamin D deficieny are insidious, or nonspecific, it often goes unrecognized and therefore untreated. In Saudi Arabia, with abundant sunshine, Vitamin $\mathrm{D}$ deficiency remains a major public health problem, due to lack of exposure to sun in the appropriate times.

This review, highlights the history of vitamin D and it's deficiency in Saudi Arabia, causes, risk factors, pathophysiology, clinical presentation, and diagnosis and suggests strategies for its prevention and treatment.

Keywords: Deficiency; Vitamin D; Rickets; Sunny Country; Saudi Arabia.

\section{Introduction}

Vitamin D deficiency is an important health problem in bone development World wide [1-19].

Vitamin D deficiency results in a failure of osteoid to calcify in a growing person (Rickets), while failure of osteoid to calcify in adults is called osteomalacia. The term rickets comes from the old English word "wricken" meaning to twist or bend. Rickets occurred in humans as early as the second century AD. The disease was not considered a significant health problem until the industrialization of Northern Europe. In the $17^{\text {th }}$ century, Whistler, De Boot and Glissen independently recognized that many of the children who lived in the crowded and polluted cities in Northern Europe developed a severe bone-deformity disease characterized by enlargement of the epiphyses of the long bones and rib cage, bowing of the legs, bending of the spine, and weak and toneless muscles. Figure $1 \& 2$.

Much debate has taken place over the definition of vitamin D deficiency. Most agree that a $25(\mathrm{OH}) \mathrm{D}$ in concentration of less than $50 \mathrm{nmol} / \mathrm{L}$ or $20 \mathrm{ng} / \mathrm{ml}$ is an indication of vitamin D deficiency, whereas a $25(\mathrm{OH}) \mathrm{D}$ concentrationof $51-74 \mathrm{nmol} / \mathrm{L}$, or $21-29 \mathrm{ng} / \mathrm{ml}$, is considered to be indicative of insufficiency. Concentrations of $>30 \mathrm{ng} / \mathrm{ml}$ or $>75 \mathrm{nmol} / \mathrm{L}$ are considered to be sufficient. Since 1650 , scientists and physicians throughout Europe began to search for the cause of childhood rickets. In 1822, Sniadecki observed that children living in Warsaw had a high incidence of rickets, whereas children living in rural areas outside Warsaw did not have such an observation. He advocated exposure to sunlight as a means of curing the disease.The major breakthrough in understanding rickets was in the period (1910-1930) where the chemical structures of Vitamin D were determined [20-25].

Recent reports on the extra skeletal effects of vitamin D deficiency or insufficeicnny of vitamin D are increasing. It has been associated with autoimmunity, systemic lupus erythrematosus (SLE), psoriasis, diabetes mellitus, multiple sclerosis, Crohn's disease, hypertension, dental caries, psychological disorders such as depression and Schizophrenia, cardiovascular disorders, many common cancers $[6,19,23-35]$ and others.

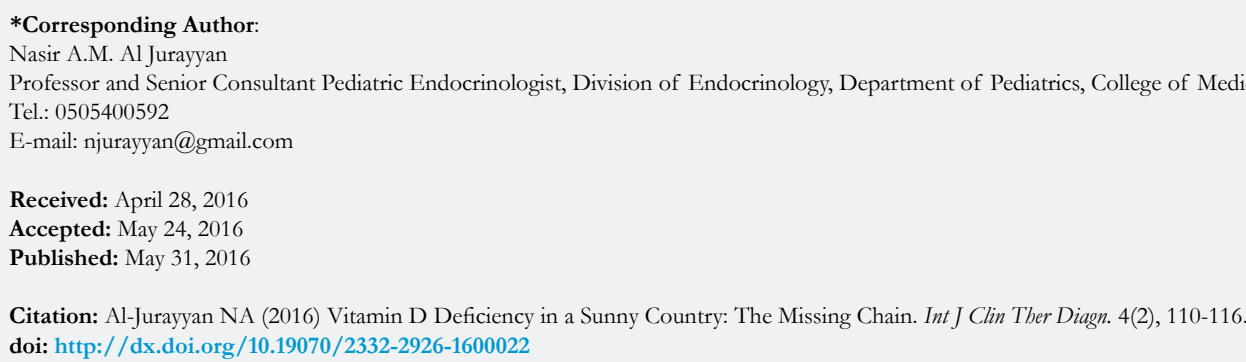

Copyright: Al-Jurayyan NA ${ }^{\circ}$ 2016. This is an open-access article distributed under the terms of the Creative Commons Attribution License, which permits unrestricted use, distribution and reproduction in any medium, provided the original author and source are credited. 
Figure 1. Photograph of the hand and wrist of a patient with rickets, showing swollen wrist (A) with the classical cupping and fraying of the humerus on X-ray (B).

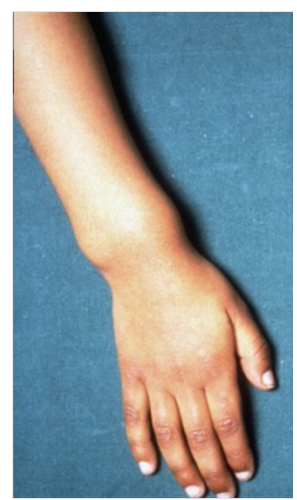

(A)

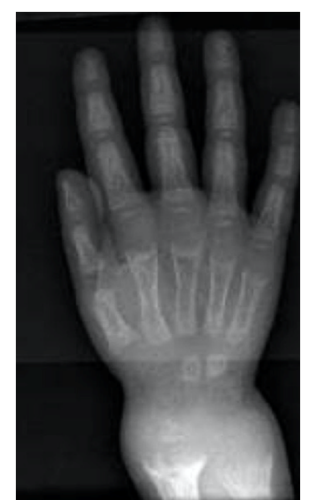

(B)

Figure 2. Photograph of a patient with rickets showing bowing of the legs (A) with classical radiological findings (B). of rickets.
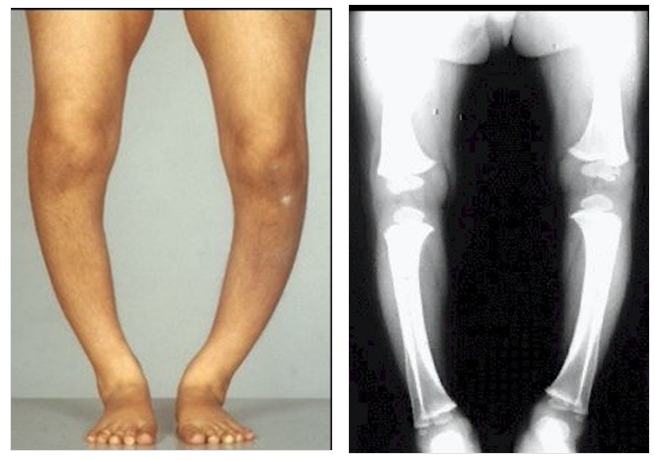

\section{Vitamin D Metabolism}

Under ultraviolet radiation, solar ultraviolet B radiation, wavelength 290 to $315 \mathrm{~nm}$ penetrate the skin and convert, pro vitamin D3 correct (7-dehydrocholestrol) in the skin to provitamin D3 (Figure 3). Provitamin D3 thermally isomerizes to Vitamin D3 in the skin. A slow process (24 hours), a carrier globulin in the blood, Vitamin D binding protein, transports Vitamin D3 from the skin to liver. In the liver, vitamin D3 is hydroxylated to 25-hydroxy-vitamin D3, which in turn is hydroxylated in the kidney to 1.25 -dihydroxy vitamin D3. The final hydroxylation process is facilitated by decreased calcium, decreased phosphorous or increased parathyroid hormone.

1, 25 Dihydroxy Vitamin D3 increases intestinal calcium and phosphorous absorption, mobilizes calcium and phosphorous from bone, and possibly retains calcium and phosphorous through its renal effect. The combined effects of 1,25 dihydroxy vitamin D3 are to increase calcium and phosphorous retention and enhance the conditions for bone mineralization. 1, 25 dihydroxy vitamin D3 fulfills rhe criteria for classification as a hormone.

In the kidney, 24, 25 dihydroxy vitamin $\mathrm{D}\left(24,25(\mathrm{OH})_{2} \mathrm{D}\right)$ is also produced from 25 hydroxy vitamin D3. This metabolite is produced in conditions and phosphorous and its production in stimulates by 1.25 dihydroxy vitamin D3. Possible functions of 24, 25 dihydroxy vitamin D3 are intestinal calcium transport, chondrocyte protein synthesis, and bone mineralization [20, 22, 25, 36-38].

\section{Vitamin D Deficiency in Saudi Arabia}

AS early as 1982, Woodhouese and Norton [39] reported low vitamin D level in ethnic Saudi Arabian population. Later Sedrani et al., $[40,41]$ confirmed the earlier findings and also found that vitamin $\mathrm{D}$ levels were not related to one regios, sex, age or season [42]. Recently, Al Dubayee et al., [43] in their national study on adolescents school based cross-sectional study through the country, showed that $95 \%$ had vitamin D deficiency. Kensarah and Azzeh [44], showed that the prevalence of vitamin D deficiency in school children in Makkah area was very high and the deficiency was higher in females by studying randomly a total of 148 health school children. Also,Siddiques and Kamfar [45] showed a similar results from the Western Saudi Arabia. Naeem et al., [46] found $28.3 \%$ of 180 apparently healthy adults, were vitamin D deficient, $39.4 \%$ were vitamin D insufficient and only $32.2 \%$ had normal vitamin D levels. El-Idrissy et al., [47] and AlElig [48] from two different regions, North Western and eastern, Saudi Arabia showed a high prevalence of vitamin D deficiency. However, there was no significant change in prevalence since the report of Sedranil earlier [49-56]. Furthermore, several hospital based studies from different hospitals in different regions of Saudi Arabia indicated a very high prevalence of vitamin D deficiency [57-66].

\section{Pathophysiology}

The ossification of osteoid cells depends on adequate levels of ionized calcium and phosphate in the extracelluar fluids which influenced by metabolites of vitamin D. As the vitamin D deficient, 


\section{Figure 3. Vitamin D metabolism.}

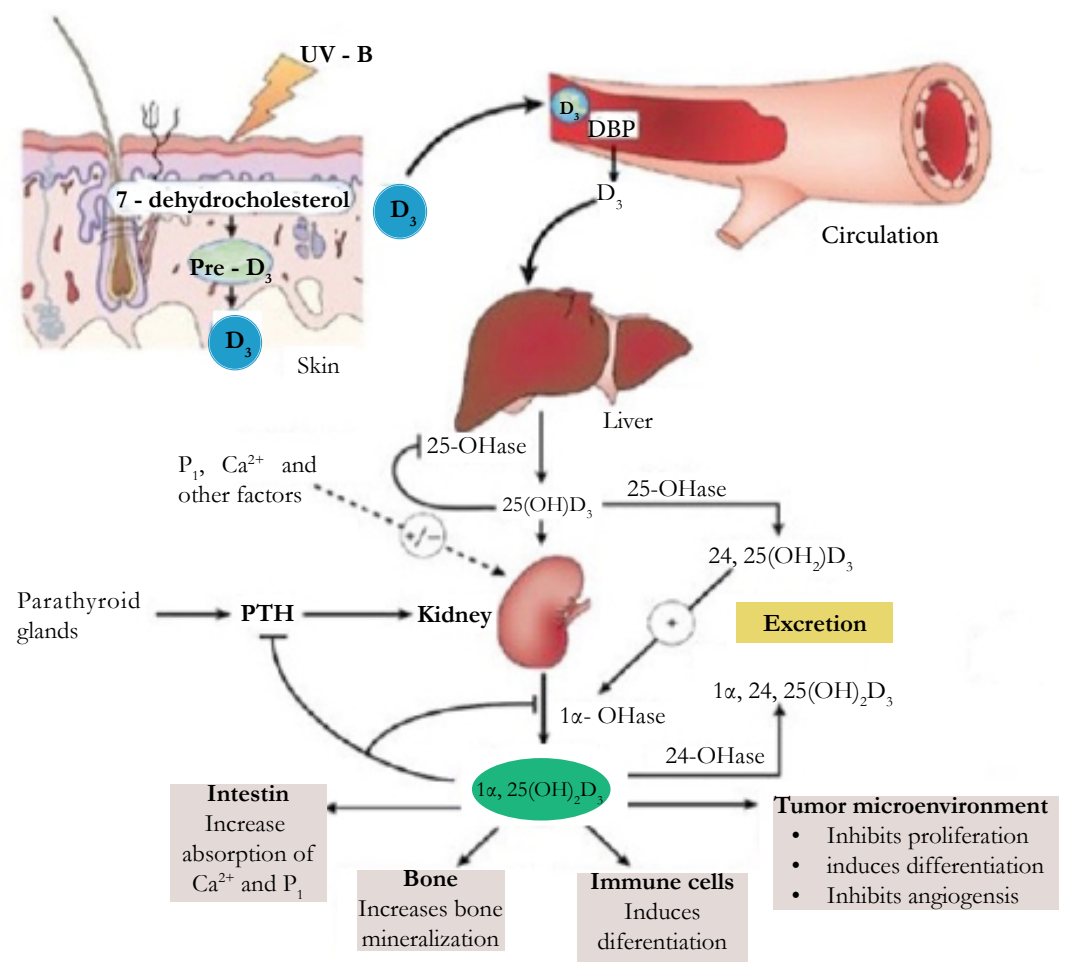

ionized calcium depletion occurs, so does parathormone PTH - hypersecretion leading to increase bone resorption and poor mineralization, hence, serum alkaline phosphatase (ALP) activity is elevated [67-69], Figure 4, and the typical radiological findings $[4,70-73]$. In rickets, anteroposterior radiography of the knees and posteroanterior radiography of the wrists show widening of growth plates, Typically the metaphysics are splayed, ragged, and concave, and the epiphyses appear as a cup. In osteomalacia, the changes are best seen in the subperiosteum, with pseudofractures as a characteristic, Figure 5. Bone scintigraphy is useful, but does not provide a diagnosis. Enhanced radiosotrope uptake occurs when osteodesis is present hence; rickets and osteomalacia can produce a "superscan", Figure 6.

\section{Sunlight and Vitamin D}

The exposure to ultraviolet radiation in the range of 290 to 315 $\mathrm{nm}$ from sunlight is the major source of vitamin D synthesis [74]. Saudi Arabia, being among the top concentrations of sunlight in the world, which lies between latitude $24-42^{\circ}$ North and Longitude $46-43^{\circ}$ East [57]. The weather is usually sunny throughout the year.However, Saudi ironically suffer from lack of vitamin D of which the sun is natural source [74].

The angle of which the sun reaches the earth has dramatic effect on the number of UVB phitons that reach the earth's surface. This is why when the Zenith angle is increasing during the winter time and in the early morning and late afternoon, little if any vitamin D3 synthesis occurs. Living at higher latitude is also associated with vitamin D3 deficiency. The best time for sun exposure to maximize vitamin $\mathrm{D}$ absorption and synthesis is between $9 \mathrm{AM}$ and 3 PM during the winter, and between $8 \mathrm{AM}$ and $10 \mathrm{AM}$ and $2 \mathrm{PM}$ and $4 \mathrm{PM}$ during the summer. The recommended period of exposure to sun is 15 - 30 minutes two to three days a week.
People with dark skin require exposure 3 to 5 times longer [7579].

\section{Risk Factors}

The physicians should be familiar with the important major risk factors associated with rickets and osteomalacia. With the realization of those, coupled with a high index of suspicion, the care taker should be able to diagnose rickets and osteomalacia. The major risk factors are: $[3,6,7,30,66,74]$.

- Dark skin ethnic population

- Exclusively breast - fed infants

- Children and those aged over 65 years

- Pregnancy

- Obesity

- Lactating mothers

- Malnutrition or low milk or dairy products intake

- Vegetarianism

- Cold environment

- Living in countries at high latitude or crowded high rise buildings

- Family history of vitamin D deficiency

- Routine covering of the face and body

- Housebound or institutional

- Prematurity or small for gestational age

- Medications such as steroids and anticonvulsant drugs

\section{Causes of rickets and osteomalacia}

The following are the major causes of rickets and osteomalacia.

\section{- Primary vitamin D deficiency}

o Classic vitamin D deficiency - infants and puberty 
Figure 4. Pathophysiology of Vitamin D.

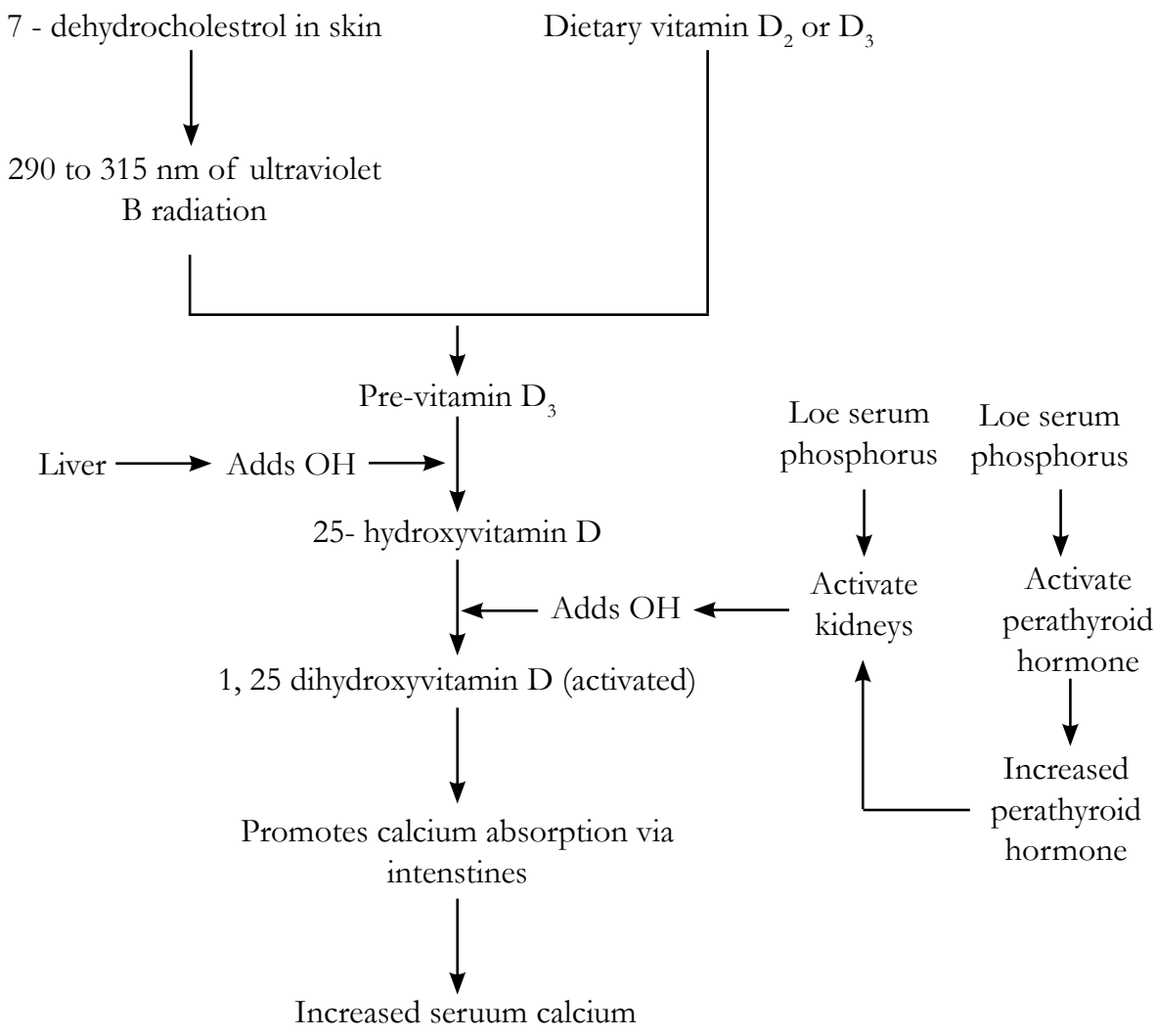

Figure 5. Anteropsterior view of the pelvis, showing Looser's zone (pseudofracture) in the femur in a patient with osteomalacia.

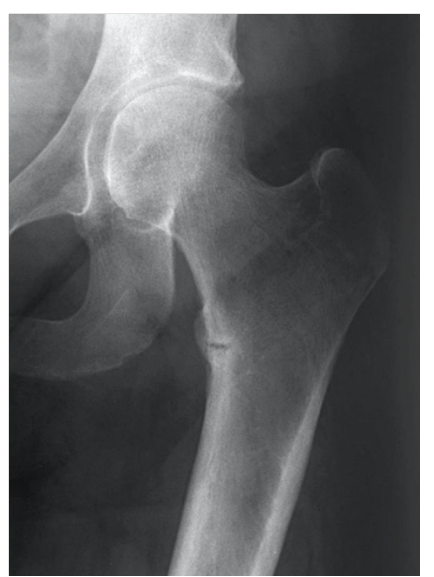

Figure 6. A whole body $\mathrm{Tc}^{99 \mathrm{~m}}$ scan (A) and (B), in a patient with osteomalacia. Note, the multiple hot spots 'superscan' i.e. multiple stress fractures in various areas of the body.

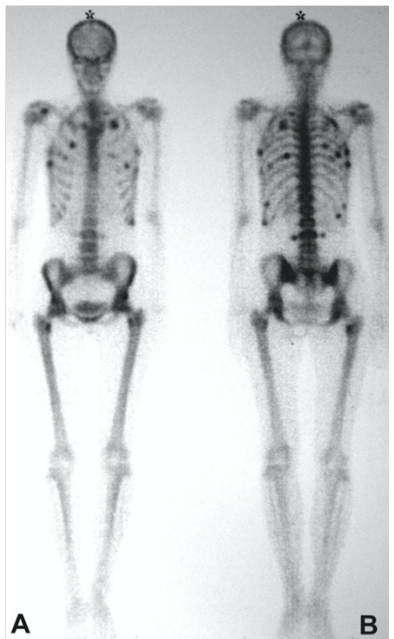


o Exclusively breast fed

o Immigrant adults in industrialized countries

o Decreased exposure to sunlight

o Use of sunscreen

o Elderly, housebound and institutionalized groups

o Pregnancy and lactation

Food faddist or reduced dietary intake.

o Morbid obesity

- Secondary vitamin D deficiency

o Partial gastrectomy

o Small bowel malabsorption syndromes (e.g. coeliac disease)

o Hepatobiliary disease

o Pancreatic insufficiency

o Chronic renal failure

o Metabolic acidosis

o Drugs and toxins

- Anticonvulsants

- Phosphate - binding antacids (e.g. aluminum hydroxide)

- Bisphosphonate (etidronate sodium)

- Steroid

- Flouride

- Miscellaneous forms

o Calcium depletion

o Magnesium depletion

o Primary hyperparathyroidism

o Oncogenic

\section{- Hereditary forms}

o Hypophosphataemia (X-linked, autosomal dominant and recessive forms)

o Vitamin D-dependent rickets Type 1 and Type 2

o Proximal renal tubular disorders (Fanconi's dyndrome)

o Distal renal tubular disorders (renal rickets with nephrocalcinosis and dwarfism)

o Hypophosphatasia

o Osteopetroricets

\section{Clinical manifestation of rickets and osteomalacia}

Rickets and osteomalacia may manifests with a constellation of symptoms and signs of which muscle weakness and bone pains and tenderness were among the commonest. Rickets manifests during growth and the signs are most prominent in areas where bone growth is most rapid, such as swollen wrists and ankles or bow legs. Short stature, bow - legs deformities, craniotabes, and hypocalcemic tetany are important features. While in osteomalacia in adolescents and adults may cause non-specific symptoms.

A high index of suspicion in the right clinical context is necessary for diagnosis. An underlying etiology is often suggested by detailed medical history $[1-3,6,80]$.

\section{Treatment and Prevention}

Once laboratory and radiologic tests confirmed the diagnosis of vitamin D deficiency rickets or osteomalacia. Vitamin D supplementation, (Table), Until serum alkaline phosphatase level and skeletal deformities return to normal. Calcium should also be supplemented. Additionally, recommending a diet rich in calcium are vitamin $\mathrm{D}$ is advisable.

Currently, no clear recommendation whether or how to screen for vitamin D deficiency rickets or osteomalacia. Both patients and physicians need to be aware of the problem and the known risk factors. Therefore, efforts to encourage exposure to sunlight in the appropriate time, and a diet rich in vitamin $\mathrm{D}$ and calcium can help to prevent vitamin D deficiency. Vitamin D is found in large amounts in fortified dairy products, such as milk and yogurt, cereals, bread, egg yolks and fish oils. Finally, patients on anticonvulsant medications or steroid should be screened periodically for ostemalacia and rickets and also if they are at a high risk should be started on vitamin D and calcium supplements as prophylaxis. Therefore, in summary education measures, appropriate vitamin D and calcium supplement, and appropriate sun exposure mandatory to prevent osteomalacia and rickets $[7$, 80-88].

\section{Acknowledgement}

The author would like to thank Mrs. Cecile S. Sael for her secretarial assistance and extend his thanks and appreciation to his daughter Miss Hadeel N. Al Jurayyan for her help and support and the College of Medicine Research Center, Deanship of Scientific Research, King Saud University, Riyadh, Saudi Arabia for supporting this work.

Table: Pharmaceutical preparations of vitamin $\mathrm{D}$ and active metabolites.

\begin{tabular}{|c|c|c|c|c|c|}
\hline & Calciferol & Dihydrotachysterol & Calcifediol & Calcitriol & Alfacalcidiol \\
\hline Drug & $\begin{array}{c}\text { Vitamin } \mathrm{D}_{3} \\
\text { and } \mathrm{D}_{2}\end{array}$ & DHT & $\begin{array}{c}25-\text { Hydroxyvi- } \\
\text { tamin } \mathrm{D}_{3}\end{array}$ & $1,25(\mathrm{OH})_{2} \mathrm{D}_{3}$ & $1 \mathrm{a}(\mathrm{OH}) \mathrm{D}_{3}$ \\
\hline Form and preparation & $\begin{array}{c}\text { Capsules, } \\
0.25 \mathrm{mg} \& \\
0.25 \mathrm{mg}\end{array}$ & Liquid $0.25 \mathrm{mg} / \mathrm{ml}$ & $\begin{array}{c}\text { Capsules, } 20 \\
\& 50 \mu \mathrm{g}\end{array}$ & $\begin{array}{c}\text { Capsules, } 0.25 \& \text { \& } \\
0.50 \mu \mathrm{g} \\
\text { Injection, } 1 \mu \mathrm{g} / \mathrm{ml} \\
\text { liquid } 1 \mu \mathrm{g} / \mathrm{ml}\end{array}$ & $\begin{array}{c}\text { Capsules, } 0.25, \\
0.50 \& 1 \mu \mathrm{g} \\
\text { liquid } 2 \mu \mathrm{g} / \mathrm{ml} \\
\text { Injection, } 2 \mu \mathrm{g} / \mathrm{ml} \\
\text { in propylene glycol }\end{array}$ \\
\hline $\begin{array}{c}\text { Time to maximum } \\
\text { effect }\end{array}$ & $4-10$ weeks & $2-4$ weeks & $4-20$ weeks & $0.5-1$ week & $0.5-1$ week \\
\hline $\begin{array}{c}\text { Persistence of effect } \\
\text { after cessation }\end{array}$ & $6-30$ weeks & $2-8$ weeks & $4-12$ weeks & $0.5-1$ week & $0.5-1$ week \\
\hline
\end{tabular}




\section{References}

[1]. Parfitt AM, Avioli LV, Krfane SM (1980) Osteomalacia and related disorders Editors Metabolic bone disease and clinically related disorders. 2nd (edn) Philadelphia (PA), WB Saunders 329.

[2]. Deluca HF (2004) Overview of general physiologic features and functions vitamin D. Am J Clin 80(6 Suppl): 1689s-1696S.

[3]. Holick MF, Chan TC (2008) Vitamin D deficiency of a world-wide problem with health consequences. Am J Clin Nut 87(4): 10805-10865.

[4]. Shore RM, Chesney RW (2003) Rickets Part II. Pediatr Radiol 43(2): 15272

[5]. Nield, LS, MahaJan P, Joshi A, Kamat D (2006) Rickets: Not a disease of the past. Am Fam Physician 74(4): 619-626.

[6]. Elder CJ, Bishop NJ (2014) Rickets. Lancet 383(9929): 1665-1676.

[7]. Holick MF (2003) Vitamin D. A millennium perspective. J Cell Biochem 88(2): 296-307.

[8]. Ward LM, Gaboury I, Ladhani M, Zlokin S (2007) Vitamin D deficiency rickets among children in Canada. CMAJ 177(2): 161-166. Doi:10.1503/ CMAJ 061377.

[9]. Robinson PD, Hogier W, Graig M et al. (2006) The re-emerging burden of rickets: a decade of experience from Sydney. Am Dis Child 91(7): 564-568.

[10]. Ward LM, Gaboury I, Ldhani M, Zlotkin S. (2005) Vitamin D deficiency rickets among Canadian infants and mothers. CMA J. 172(6): 769-770.

[11]. Rowe PM (2001) Why is rickets resurgent in the USA? Lancet 357(9262): 1100-1101.

[12]. Allgrove J (2004) Is nutritional rickets returning? Arch Dis Child 89(8): 699-701.

[13]. Karrar ZA (1998) Vitamin D deficiency rickets in developing countries. Ann Trop Paediatr 18: 89-92.

[14]. Bhan A, Rao AD. Rao DS (2010) Osteomalacia as a result of vitamin D deficiency. Endocrinol Metab Clin N AM. 39(2): 321-331.

[15]. Agarwal A, Gulati D (2009) Early adolescent nutritional rickets. J Orthop Surg 17(3): 340-345.

[16]. Weisberg P, Scanlon KS, Li R et al. (2004) Nutritional rickets among children in the United States: review of cases reported between 1986 and 2003. Am J Clin Nutr 80(6 suppl): 16977-1705(s).

[17]. Holick MF (2007) Vitamin D deficiency. N Engl J Med 357(3): 266-281.

[18]. Prentice PR (2008) Vitamin D deficiency: a global perspective. Nutr Rev 66(10 suppl 2): 153-164.

[19]. Wharton B, Bishop N (2003) Rickets. Lancet 362(9393): 1389-1400.

[20]. Martins e Silva J (2007) Brief history of rickets and of the discovery of vitamin D. Acta Rhematol Port 32(3): 205-229.

[21]. Rajakumar K, Holick MF (2012) Vitamin D deficiency: historical perspective. Vitamin D and the lung, Mechanisms and Disease Associations. Respiratory Medicines. Springed Science and Business Medicine LLC.3: 3-23. 10.1007/978-1-61779-888-7_1.

[22]. Holick MF (1991) Pathogenesis, metabolism and biological nature of Vitamin D. In: Glorien FH ed. Rickets. NY Raven Press (2): 1-22.

[23]. Hernigou P (1995) Historical overview of rickets, osteomalacia and vitamin D. Rev Rheum Engl Ed 62(4): 261-270.

[24]. Olson EB Jr, De Luca HF (1973) Vitamin D metabolism and mechanism of action. World Rev Nut Diet 17: 164-88.

[25]. Holick MF (1991) Photosynthesis, metabolism, and histological actions of vitamin D . Raven Press, New York (2): 1-22.

[26]. Gronli O, Kramme JM, Jorde R, Wynn R (2014) Vitamin D deficiency is common in psychogeriatric patients independent of diagnosis. BMC Psychiatry 14: 134-139.

[27]. Boudal AM, Attar SM. Vitamin D and autoimmune disease, insights and perspectives in rheumatology. Harrison A, ed. ISBN 978-953-307-846-5.

[28]. Attar SM (2012) Vitamin D deficiency in rheumatoid arthritis: prevalence and association with disease activity in Western Saudi Arabia. Saudi Med J 33(5): 520-525.

[29]. Fouda MA, Turkistani IZ, Angkaya-Bagayawa FF, Krishnaswamy S, Al Daghri N (2016) Vitamin D deficiency in young women of childbearing age: the elephant in the room. Int J Clin Exp Med 9(2): 4615-4619.

[30]. Holick MF, Chen TC (2008) Vitamin D deficiency: a worldwide problem with health consequences. Am J Clin Nut 87(4): 1080-1086.

[31]. Damanhouri LH (2009) Vitamin D Saudi patients with systemic lupus erythrematosus. Saudi Med J 30(10): 1291-1295.

[32]. Bin-Abbas BS, Al Jabari MA, Al Issa SD, Al Fares AH, Al Muhsen S (2011) Vitamin D levels in Saudi child with type 1 diabetes. Saudi Med J 32(6): 589-592.

[33]. Ghada El-Hajj Fuleihan (2010) Vitamin D deficiency in the Middle East and its health consequences, Nutrition and Health. Humana Press,USA. 469-494.

[34]. Fuad H, Al-Madi EM, Latheef F (2014) Influence of vitamin D deficiency and breast cancer on incidence of periodontal disease in females. Journal of Dental and Medical Research 13(4): 1-5.

[35]. Al Faraj S, Al Mutairi K (2003) Vitamin D deficiency and chronic low back pain in Saudi Arabia. Spine 28(2): 177-179.

[36]. Kruse K, Barlels H, Kracht L (1984) Parathyroid function in different stages of vitamin D deficiency rickets. Eur J Pediatr 141(3): 158-162.

[37]. Martin A, David V. Laurence JS et al. (2008) Degradation of MEPE, DMPI, and release of SIBLING ASARM-peptides (minhibins): ASARMpeptides(s) are directly responsible for defective mineralization in HYP. Endocrinology 149(4): 1757-1772.

[38]. Fraser DR (1991) Physiology of vitamin D and calcium homeostasis, Netle Nutrition Workshop Series. Raven Press, New York, USA. 23-31.

[39]. Woodhouse NJY, Norton WL (1982) Low vitamin D levels in Saudi. Arabians. King Faisal Spec Hosp Med J 127-131.

[40]. Sedrani SH, Abanamy A, Salman HM, Al Arabi K, El Idrissy AT (1992) Vitamin D status of Saudi children. Are Saudi children at risk of developing vitamin D deficiency rickets. Saudi Med J 13: 430-433.

[41]. Sedrani SH (1986) Are Saudis at risk of developing vitamin D deficiency? Saudi Med J 7: 427-433.

[42]. Sedrani SH, El Arabi Abanmy A, El Idrissy AWTH (2007) Vitamin D status of Saudis II. Effect of regional and environmental location. Saudi Med J 13: 206-213.

[43]. Al-Dubayee M, Al Buhairan F, Al Alwan et al. (2014) Vitamin D deficiency: A national threat to adolescent health in Saudi Arabia. ESPE Abstracts 82 p-d-1-2

[44]. Kensarah OA, Azzeh FS (2012) Vitamin D status of healthy school children from Western Saudi Arabia. Pakistan J Nut 11(3): 288-292.

[45]. Siddiqui AM, Kamfar HZ (2007) Prevalence of vitamin D deficiency rickets in adolescent school girls in Western region, Saudi Arabia. Saudi Med J 28(3): 441-444.

[46]. Naeem Z, Al Mohammed A, Sharaf FK, Ismail H, Shaukat F, Basmilnam SN (2011) Vitamin D status among population of Qassim Region, Saudi Arabia. International JH Sci( Qassim) 5(2): 116-124.

[47]. El-Idrissy ATH, Sandokji AM, Al Magamsi MF, Al Hawsawi ZM, Al Hujaili AS, Babiker NH (2012) Nutritional rickets in Al Madinah Al Munawarah: presentation and associated factors. J Taibah Univ Med Sci 7(1): 35-40.

[48]. Al Eliq AH (2012) The status of vitamin D in medical students in the preclarkship of Saudi Medical School. J Family Community Med 19(2): 100104.

[49]. El Sammak MY, Al Wosaibi AA, Al Howeish A, Al Saeed J (2010) Vitamin D deficiency in Saudi Arabia. Horm Res 42: 364-368.

[50]. Al-Turki HA, Sadat-Ali M, Al-Elq AH, Al-Mulhim FA, Al Ali AK (2008) 25-hydroxy vitamin D levels among healthy Saudi Arabia women. Saudi Med J 29(12): 1765-1768

[51]. Sadat-Ali M, Al Eli A, Al Turki H, Al Mulhin F, Al Ali A (2009) Vitamin D levels in healthy Eastern Saudi Arabia. Ann Saudi Med 29(5): 378-382.

[52]. Ali A, Amin L, Al-Ali A (2012) Vitamin D level among students I College of Nursing in Saudi Arabia and its relation to student symptoms. J Am Sci 8(11): 132-138.

[53]. Al Harbi AS, Al Omery Hedaib SM (2013) Prevalence of vitamin D deficiency among healthy Saudi Men. Sch J App Med Sci 1(6): 863-866.

[54]. Kensarah O, Jasar AS, Azzah FS (2015;) Hypovitaminosis D in healthy toddlers and preschool children from Western Saudi Arabia. Int J Vitamin and Nutrition Res 85(1-2): 50-60.

[55]. El Shafie DE, Al Khashan HI, Mistiriky AM (2012) Comparison of vitamin D deficiency. Auro J Clin Nut 66(6):742-745.

[56]. Al- Faleh K, Al Manie AM, Al Mahmoud HF et al. (2014) Prevalence of vitamin D deficiency in Saudi newborns at a tertiary care center. Saudi Med J 35(2): 178-182.

[57]. Abdullah MA, Salhi HS, Bakry LH et al. (2012) Adolescent rickets in Saudi Arabia: a rich and sunny country. J Pediatr Endocrinol Metabol 15(7): 1017-1025.

[58]. Al-Jurayyan NAM, El-Desouk MI, Al-Herbish AS, Al Mazyad AS, Al Qahtani MM (2002) Nutritional rickets and osteomalacia in school children and adolescents. Saudi Med J 23(2): 182-185.

[59]. Al Jurayyan NA, Mohamed S, Al Issa S, Al Jurayyan AzN (2012) Rickets and osteomalacia in Saudi children and adolescents attending endocrine clinic, Riyadh, Saudi Arabia. Sudanese J Pediatr 12(1): 56-63.

60]. Erfan AA, Nafie OA, Neyaz AH (1997) Hassanien MA. Vitamin D deficiency rickets in maternity and children's hospital, Makkah, Saudi Arabia. Ann Saudi Med 17(3): 371-373.

[61]. Al Atawi MS, Al Alwan IA, Al Mutair AN, Tamimi HM, Al Jurayyan NA (2009) Epidemiology of nutritional rickets in children. Saudi J Kidney Dis and Transplant 20(2): 260-265.

[62]. Hazzazi MA, Al Zeer I, Tamimi W, Al atawi M, Al Alwan I (2013) Clinical presentation and etiology of ostemalacia/rickets in adolescents. Saudi J Kidney Dis Transpl 24(5): 938-941. 
[63]. Abanamy A, Salman H, Cheriyan M, Shuja M, Sedrani SH (1991) Vitamin D deficiency. Ann Saudi Med 11: 35-39.

[64]. Al Jurayyan NA, Al Jurayyan AN, Al Jurayyan RN, Al Jurayyan AzN, Al Issa SD (2014) Adolescents osteomalacia in Saudi Arabia. A hospital based study. Eur J Res Med Sci 2(2): 59-64.

[65]. Kanan R, Al Saleh YM, Fakhoury HM, Adham M, Al Jaser S, Tamimi W (2013) Year-round vitamin D deficiency among Saudi female outpatients. Public heath Nutrition 16(3): 544-548.

[66]. Holick MF Vitamin D (2010) Extraskeletal Health. Endocrinol Metabolism Clin Nam. 39(2): 381-400.

[67]. Bingham CT, Fitzpatrick LA (1993) Non-invasive testing in the diagnosis of osteomalacia. Am J Med 95(5): 519-522.

[68]. Al Jurayyan NA, Al Jurayyan AN, Al Omran H, Al Jurayyan AN, Babiker AM (2015) Alkaline phosphatase (ALP) activity as a marker for vitamin D deficiency. AM J Res Com 3(5): 1-9.

[69]. Vasudevan J, Jenifer A, Reddy GMM Thayumanavan S (2014) Serum alkaline phosphatase for screening of hypovitaminosis D. Indian Pediatr 51(1): 60-61.

[70]. Pitt MJ(1996 ) Rickets and osteomalacia, Bone and joint imaging. (2nd edn) WB Saunders, Philadeplphia. 511-524.

[71]. Renton P (1998) Radiology of rickets and osteomalacia and hyperparathyroidism. Hosp Med 59(5): 399-403.

[72]. Kottamasu SR (2004) Metabolic bone disease, Caffey's Pediatric Diagnostic Imaging. (10th edn). Philadelphia, Pa Mosby 2242-2253.

[73]. Caunell JJ, Holis BW, Zaslu M, Heamey RP (2008) Diagnosis and treatment of vitamin D deficiency. Expert opin Pharmacesther 9(1): 107-118.

[74]. El-Idrissy AT (1987) Vitamin D deficiency: Rickets in a sunny country: pathogenesis, clinical picture and management. Ann Saudi Med 7: 119-125.

[75]. Green PR, Marshal S (1989) Bone mineral content, serum vitamin D metabolite concentration and ultraviolet B light exposure in infants fed human milk with and without vitamin D2 supplementals. J Pediatr 114(2): 204-212.

[76]. Al Sharani F, Al Malki, Al Johani N, Al Zahrani, Al Saleh Y, et al. (2013)
Vitamin D: Light side and best time of sunshine in Riyadh, Saudi Arabia. Bone abstract 1pp126 DOI: 10-1530/boneabs/pp126.

[77]. Al Shahrani F, Al Saleh Y, Saeedi MV, Al Malki MH, Al DAghri N,et al. (2015) Optimum sun exposure times for vitamin D status. Correction in Saudi Arabia. Eur J Preventive Med 3(5): 147-154.

[78]. Tamimi W, Kanan R, Adnan M, Al Jasser S (2011) Seasonal variation of vitamin D level among menopausal and post menopausal Saudi women. Endocrine Abstracts 25: 31-34.

[79]. Holick MF (1995) Environmental factors that influence the cutaneous production of vitamin D. Am J Clinic Nutr 61(3) : 6385-6435.

[80]. Pearce SH, Cheethan TD (2010) Diagnosis and management of Vitamin D deficiency. BMJ 340: 5664-5672.

[81]. Misra M, Pacand D, Petyk A, Collet-Solberg PF, Kappy M (2008) Vitamin $\mathrm{D}$ deficiency in children and its management. Review of current knowledge and recommendation. Pediatrics 122(2): 398-417.

[82]. Spence JT, Serwint JR (2004) Secondary prevention of vitamin D deficiency rickets. Pediatrics 113(1): e70-e72.

[83]. Holick MF (2006) The role of vitamin D for bone health and fracture prevention. Curr Osteoporosis Rep 4(3): 96-102.

[84]. Wagner CL, Geer FR (2008) Prevention of rickets and vitamin D deficiency in infants, children and adolescents. Pediatrics 122(5): 1142-1152.

[85]. Muuns CF, Shaw N, Kiely M et al. (2010) Global consensus recommendations on prevention and management of nutritional rickets. Horm Res Paediatr 85(2): 83-106.

[86]. Qari FA (2013) Practical approach for the prevention and management of vitamin D deficiency in adults. J Family Med Prim Care 2(4): 315-318.

[87]. Al Reshidi ID (2015) Vitamin D deficiency in children: a review on prevention and treatment strategy. International Current Pharacentrical J 5(1): 5-8.

[88]. Al Jurayyan NAM, Al-Jurayyan ANM, Al-Jurayyan RNA, Al Jurayyan AzN (2015) Rickets and osteomalacia in Saudi Arabia: The need for a national preventive program. Eur J Res Med Sci 3(1): 21-30. 